\title{
SLOVENIAN EXONYMS IN NORTH AMERICA
}

Drago Perko, Drago Kladnik

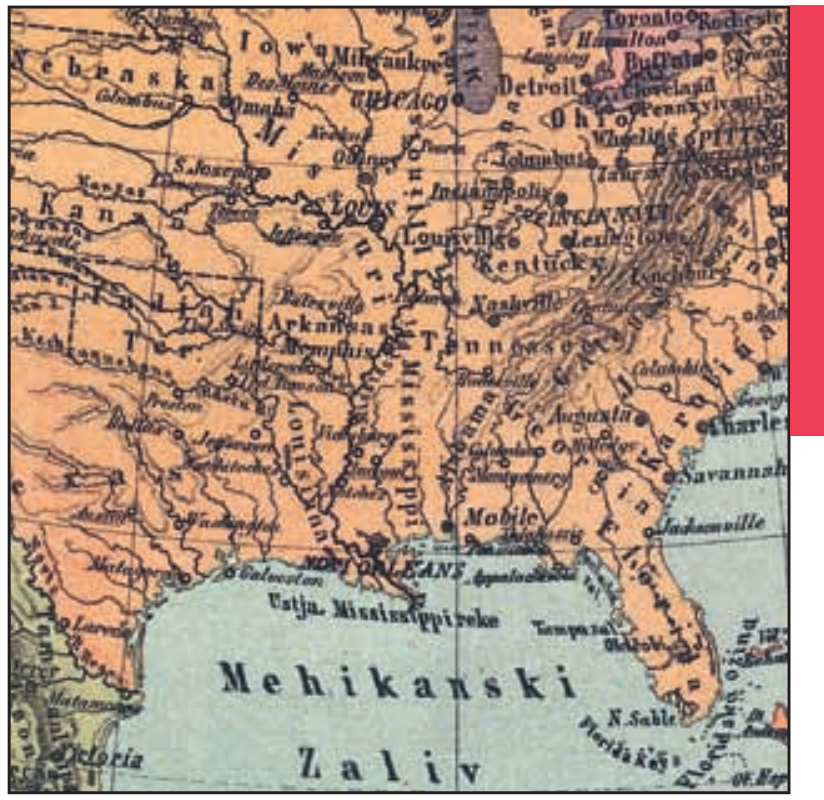

Section of the map of North America from Atlant (1869-1877), the first world atlas in Slovenian. 


\section{Slovenian exonyms in North America}

DOI: http://dx.doi.org/10.3986/AGS.4777

UDC: 91:811.163.6'373.21

COBISS: 1.01

ABSTRACT: The number of Slovenian exonyms around the world decreases with distance from Slovenia. This applies less so to North America, where their density is twice as high as in South and Central America. Based on a comparative analysis of geographical names from all important world atlases in Slovenian, we prepared two spreadsheets of Slovenian exonyms. The extensive spreadsheet has 5,038 names and the concise spreadsheet has 3,819 names. Each exonym has thirty-five thematic fields.

In North America, marine hydronyms (21.1\%) are the most numerous semantic type of exonyms, and completely translated names (77.9\%) are the most numerous Slovenianized type of exonyms. Among the original languages of exonyms, English completely prevails (97.1\%).

The most commonly used Slovenian exonyms from North America in Slovenian texts are Dolina smrti »Death Valley«, Veliki kanjon »Grand Canyon«, Niagarski slapovi »Niagara Falls», Skalno gorovje »Rocky Mountains«, and Aleuti »Aleutian Islands«.

KEY WORDS: geographical name, endonym, exonym, Slovenian, Slovenianization, North America, United States, Canada

The article was submitted for publication on November $15^{\text {th }}, 2016$.

\section{ADDRESSES:}

\section{Drago Perko, Ph.D.}

Anton Melik Geographical Institute

Research Center of the Slovenian Academy of Sciences and Arts

Novi trg 2, SI-1000 Ljubljana, Slovenia

E-mail: drago@zrc-sazu.si

\section{Drago Kladnik, Ph.D.}

Anton Melik Geographical Institute

Research Center of the Slovenian Academy of Sciences and Arts

Gosposka ulica 13, SI-1000 Ljubljana, Slovenia

E-mail: drago.kladnik@zrc-sazu.si 


\section{Introduction}

A geographical name or toponym (from Greek tópos »place« and ónyma, a dialect variant of ónoma »name«) is a proper name of a geographical feature.

An endonym (from Greek éndon »inside«) is the geographical name of a feature in one of the languages spoken in the territory of the feature. An exonym (from Greek éksō »outside«) is the geographical name of a feature in one of the languages that are not spoken in the territory of the feature, if different from the endonym of this feature (Kadmon 2000). Simply put, an endonym is the local (or original) name of a geographical feature and an exonym is a foreign name for the same feature (Kladnik 2009).

Slovenian endonyms are Slovenian geographical names within Slovenian ethnic territory, and Slovenian exonyms are Slovenian geographical names in all other territories if they differ from the endonyms there.

In the narrow sense of the word, Slovenian exonyms only include Slovenian geographical names that are completely different from the original endonyms (e.g., Nemčija for Deutschland »Germany «); in the broader sense, they also include Slovenianized and translated geographical names (e.g., Pariz »Paris« and Rumena reka »Yellow River«, Chinese Huang He).

The average density of Slovenian exonyms per million $\mathrm{km}^{2}$ is 103 in Europe, eighteen in Asia, fourteen in Africa, eight in North America, five in South America, and four in Central America.

The number of Slovenian exonyms around the world decreases with distance from Slovenia. This applies less so to North America, where the density is twice as high as in South and Central America, which is associated with the above-average global role of North America in the last century and the emigration of Slovenians in past centuries.

\section{Methods}

We collected geographical names from fourteen Slovenian world atlases, including Cigale's Atlant (Atlas, 1869-1877), the first world atlas in Slovenian (Urbanc et al. 2006; Kladnik et al. 2006), as well as some important encyclopedias (Veliki splošni leksikon... 1997-1998) and the Slovenian Orthography (Slovenski pravopis 2001).

Based on a comparative analysis of the names collected, we prepared two spreadsheets of Slovenian exonyms. The extensive spreadsheet contains 5,038 names (Internet 1) and the concise one has 3,819 names (Kladnik et al. 2013). Each exonym has thirty-five thematic fields (Table 1):

- 1) Nominative form of the Slovenian exonym;

- 2) Genitive form of the Slovenian exonym;

- 3) Adjectival form of the Slovenian exonym;

- 4) Original geographical name (endonym);

- 5) Language of the original geographical name;

- 6) Exonym location (continent, ocean);

- 7) Exonym location (country, sea);

- 8) Semantic type of the exonym;

- 9) Latitude of the exonym;

- 10) Longitude of the exonym;

- 11) Degree of Slovenianization of the exonym;

- 12) Status of the exonym according to standardization;

- 13) Recommended use of the exonym (necessary, recommended, less recommended, not recommended or unnecessary, inappropriate);

- 14) Alternative exonym (allonym);

- 15-24) Versions of the Slovenian exonym in atlases and other sources;

- 25-32) English, French, German, Spanish, Russian, Italian, Croatian, and Hungarian form of the exonym;

- 33) Etymology of the exonym;

- 34) Notes about the exonym;

- 35) Coordinates of the exonym on the map.

For exonyms from the list of 3,819 names, we produced several maps (at a scale of 1:50,000,000 for the entire world, and at some more detailed scales for certain parts of the world, especially Europe, where the density of Slovenian exonyms is higher). 


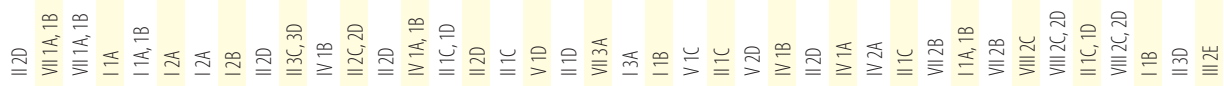

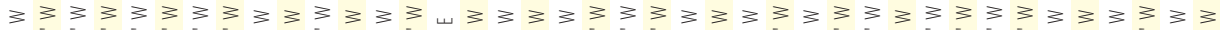

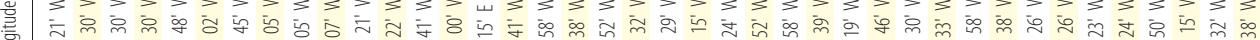

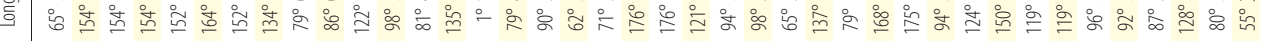

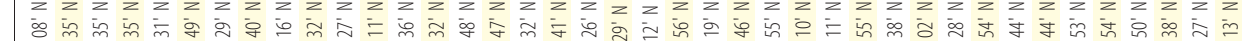

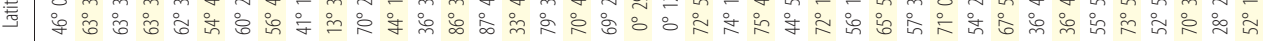

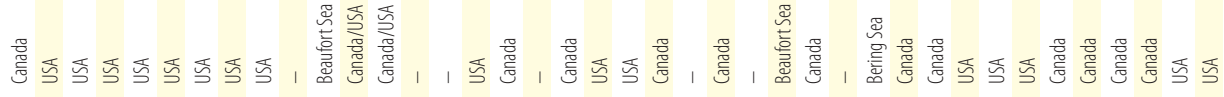

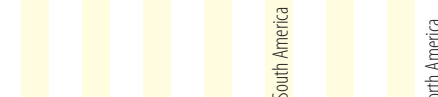

竞

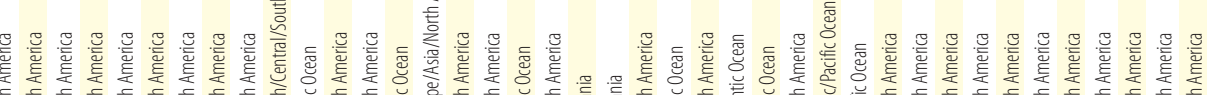

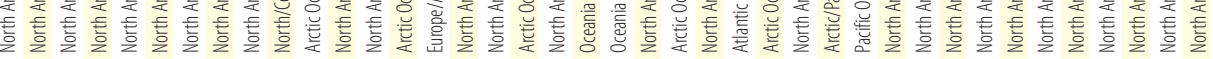

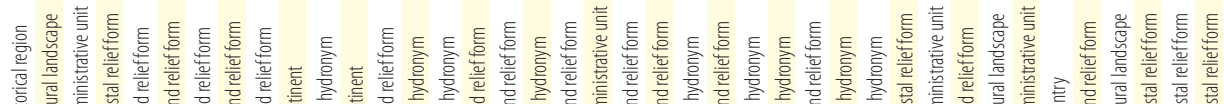

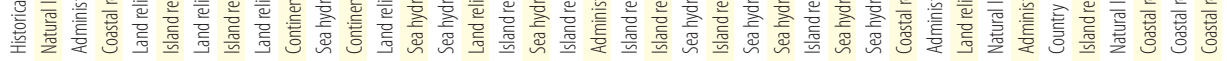

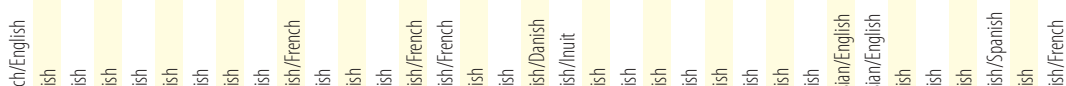

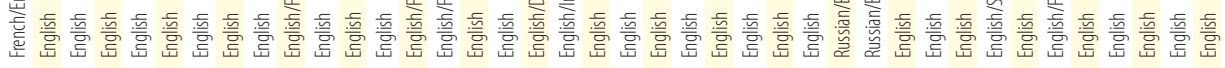<smiles>C[C@@H]1C[C@@H]1C1CC1</smiles>

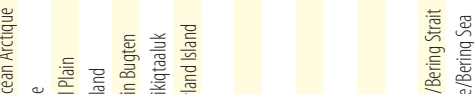<smiles>CCCC1CC1C</smiles>

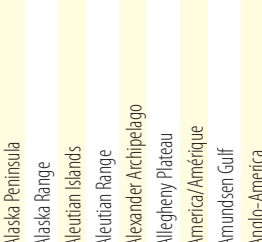

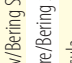

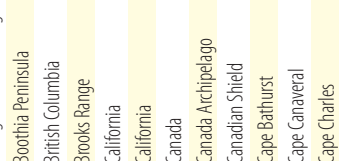




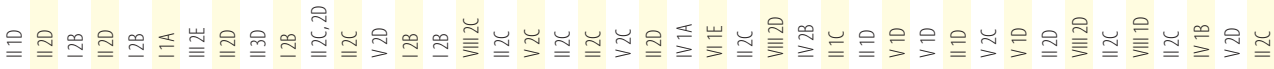

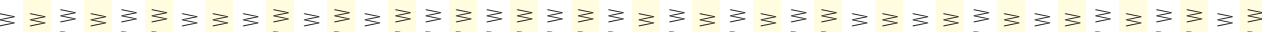

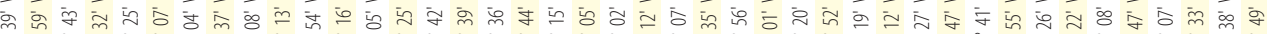

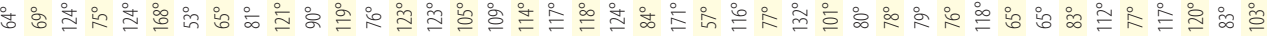

$z z z z z z z z z z z z z z z z z z z z z z z z z z z z z z z z z z z z z z z$

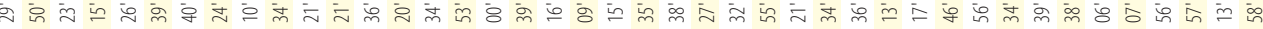

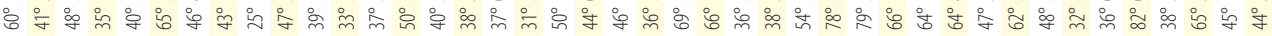

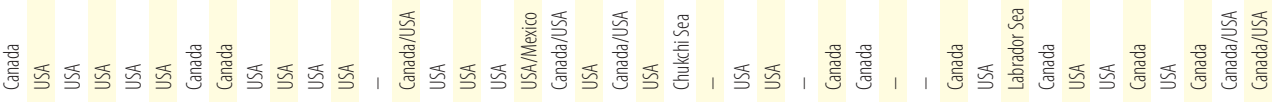

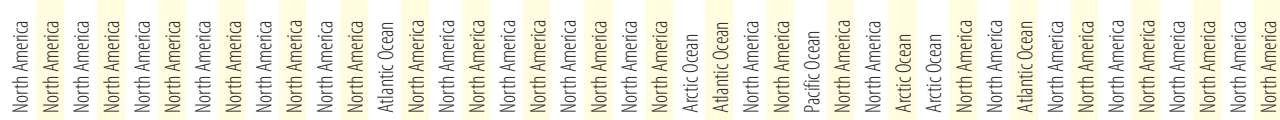

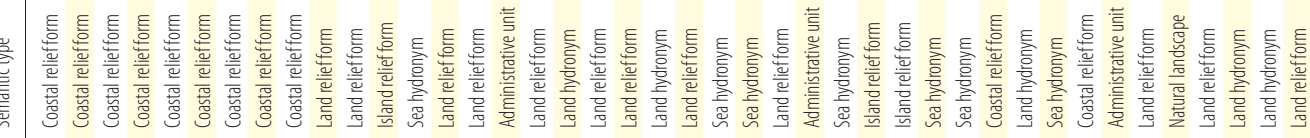<smiles>C=CCCCCC</smiles>

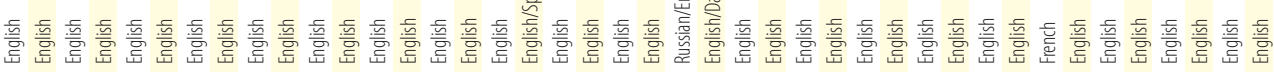

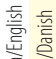

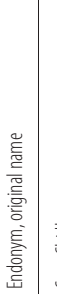

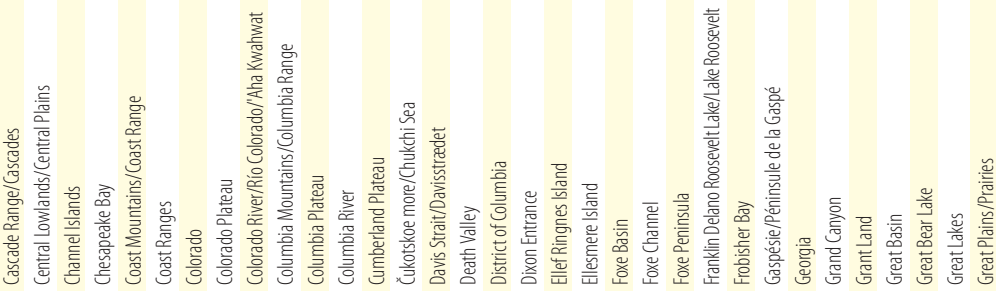

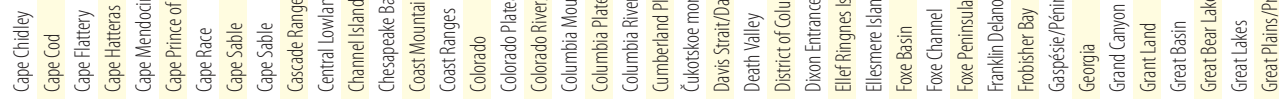

产

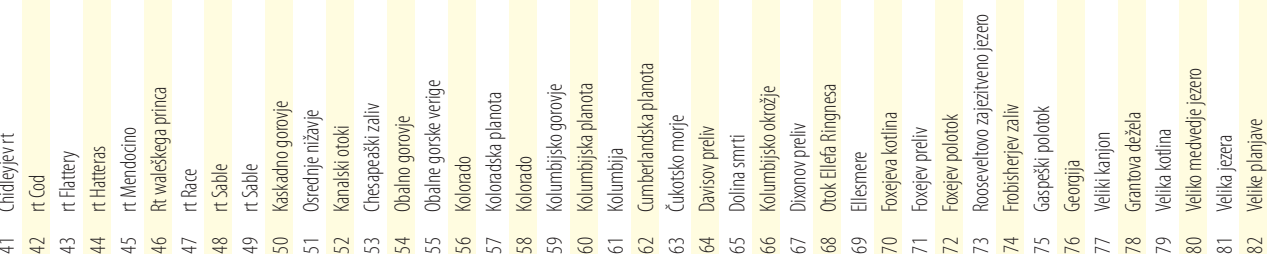




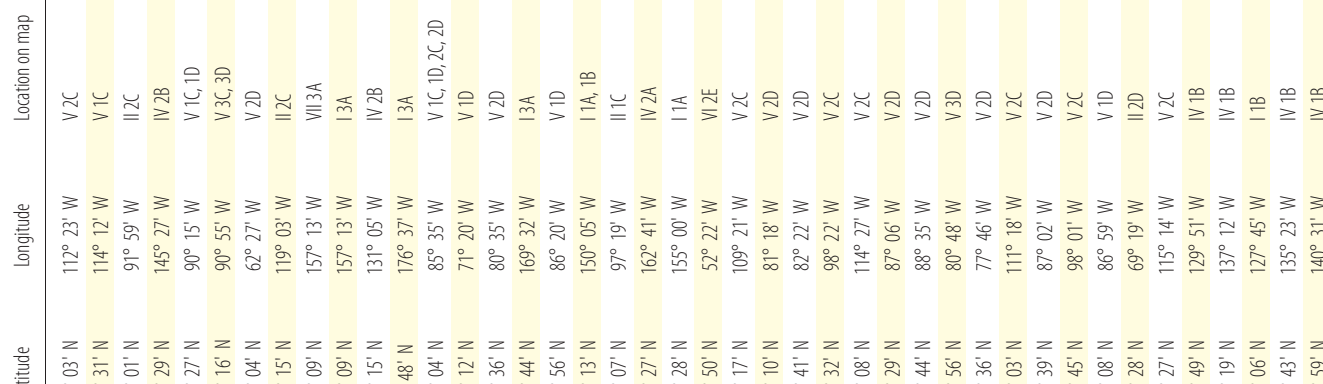

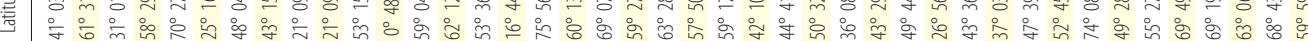

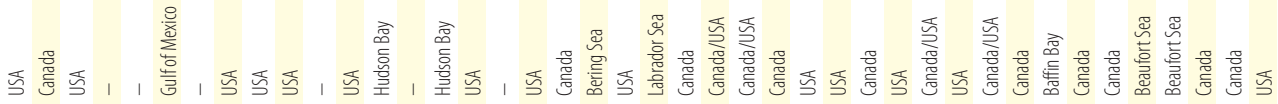

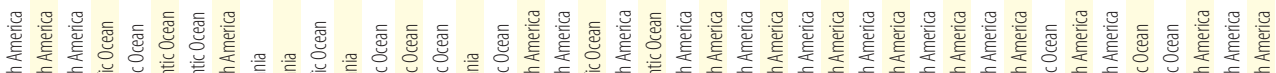

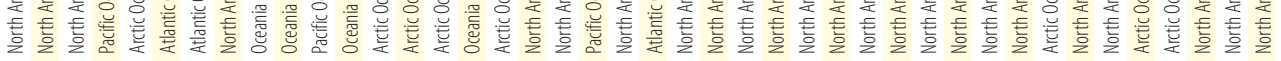

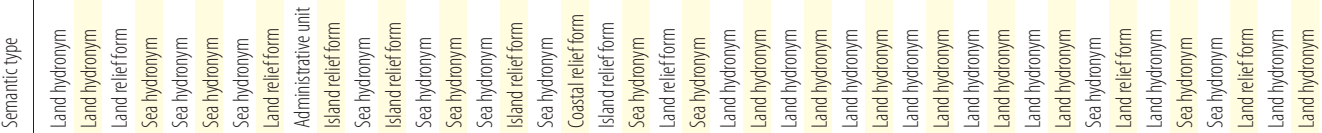

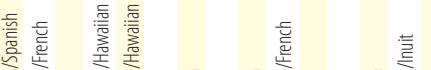

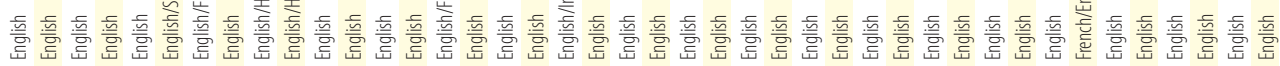




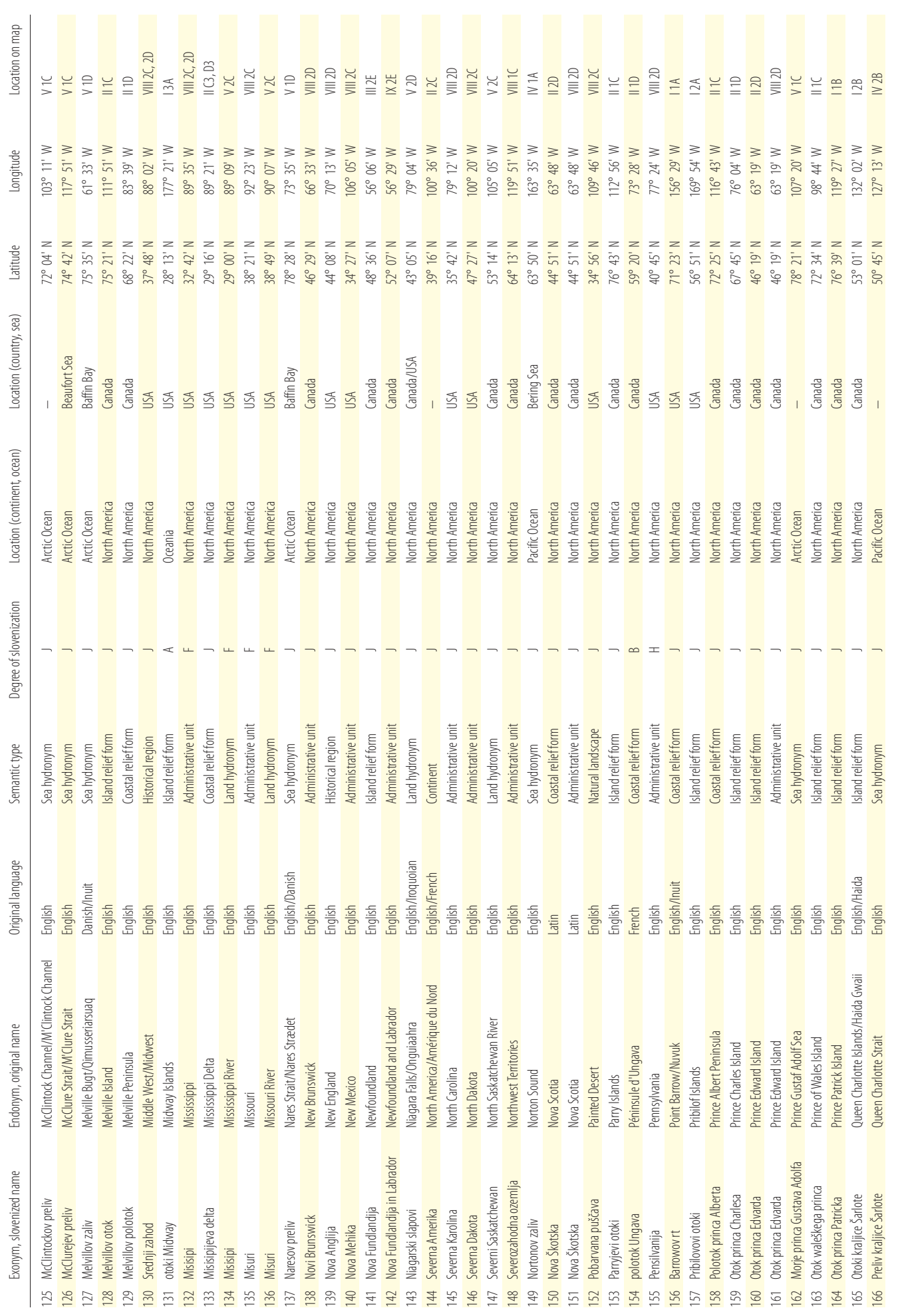




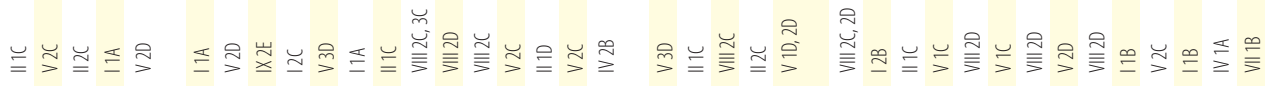

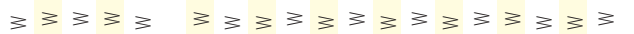

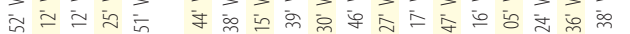

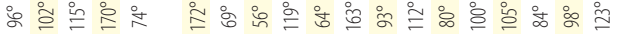

33333

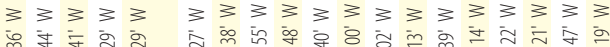

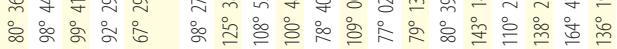

$z z z z z z z z z z z z z z z$

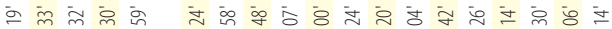

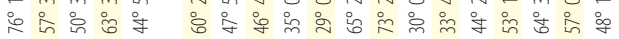

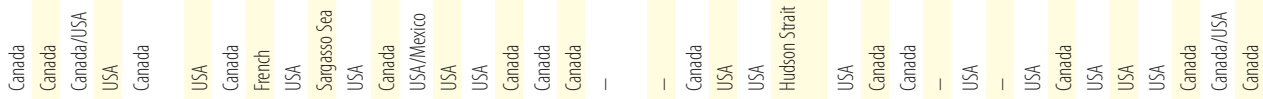

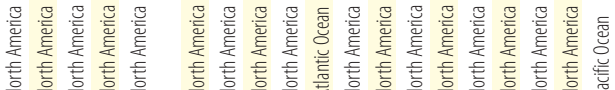

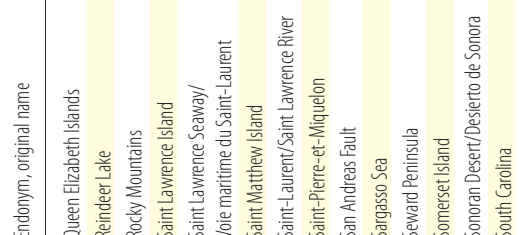

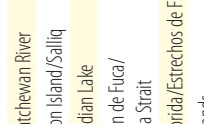<smiles>C1C2C3C1C1C2C31</smiles>

T.

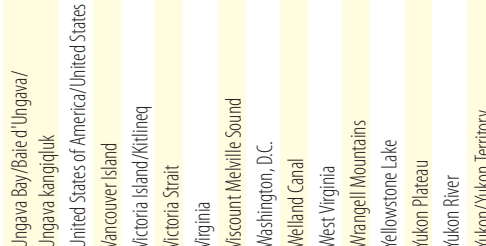

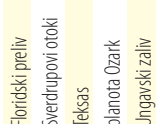

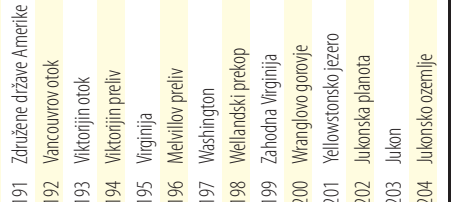


For the analysis of Slovenian exonyms in North America, we considered all of the names on the three maps (divided into three sections) at a scale of 1:50,000,000 (Figure 1) that fall within Canada and the United States (excluding Greenland and Central America) and without names of undersea features. The final number of these names is 204, and the final number of names from the list of 3,819 names without undersea features is 3,316 .

\section{Semantic types of exonyms}

We defined sixteen semantic types, which are adapted to global dimensions and the standard division of geographical features:

- Continent: in North America, the number of such exonyms is three (1.5\%; e.g., Severna Amerika »North America«, Angloamerika »Anglo-America «) compared to eleven (0.3\%) in the rest of the world (e.g., Afrika "Africa«, Evropa »Europe«).

- Country: in North America, the number of such exonyms is two (1.0\%; e.g., Kanada »Canada«, Združene države Amerike»United States of America«) compared to 171 (4.7\%) in the rest of the world (e.g., Francija "France«, Finska »Finland «).

- Settlement: in North America, the number of such exonyms is one (0.5\%; e.g., Washington »Washington, DC«) compared to 432 (12.0\%) in the rest of the world (e.g., Rim »Rome«, Atene »Athens«).

- Historical settlement: in North America there are no such exonyms (0.0\%) compared to $102(2.8 \%)$ in the rest of the world (e.g., Troja»Troy«, Bizanc »Byzantium«).

- Land relief form: in North America, the number of such exonyms is twenty-eight (13.7\%; e.g., Dolina smrti »Death Valley«, Jukonska planota »Yukon Plateau«) compared to 420 (11.6\%) in the rest of the world (e.g., Andi »Andes«, Turansko nižavje »Turan Lowland «).

- Land hydronym: in North America, the number of such exonyms is thirty-four (16.7\%; e.g., Niagarski slapovi »Niagara Falls«, Velika jezera »Great Lakes«) compared to 346 (9.6\%) in the rest of the world (e.g., Mrtvo morje »Dead Sea", Beneška laguna »Venetian Lagoon«).

- Sea hydronym: in North America, the number of such exonyms is forty-three (21.1\%; e.g., Mehiški zaliv "Gulf of Mexico«, Hudsonov preliv »Hudson Strait«) compared to 341 (9.4\%) in the rest of the world (e.g., Indijski ocean »Indian Ocean«, Rossova ledena polica »Ross Ice Shelf«).

- Undersea feature: these exonyms are not included in the article (e.g., Filipinski jarek»Philippine Trench», Agulhaška planota »Agulhas Plateau«).

- Island relief form: in North America, the number of such exonyms is thirty-four (16.7\%; e.g., Nova Fundlandija »Newfoundland «, Otok svetega Lovrenca »Saint Lawrence Island «) compared to 353 (9.8\%) in the rest of the world (e.g., Azori »Azores«, Veliki koralni greben »Great Barrier Reef«).

- Coastal relief form: in North America, the number of such exonyms is twenty-four (11.8\%; e.g., Aljaški polotok »Alaska Peninsula«, Misisipijeva delta »Mississippi Delta ) compared to 176 (4.9\%) in the rest of the world (e.g., Apeninski polotok »Apennine Peninsula", Donavina delta »Danube Delta «).

- Natural landscape: in North America, the number of such exonyms is six (2.9\%; e.g., Pobarvana puščava »Painted Desert«, Kanadski ščit »Canadian Shield «) compared to 304 (8.4\%) in the rest of the world (e.g., Dežela kraljice Maud»Queen Maud Land«, Sahara).

- Historical region: in North America, the number of such exonyms is three (1.5\%; e.g., Akadija "Acadia«, Nova Anglija »New England «) compared to 100 (2.8\%) in the rest of the world (e.g., Abesinija "Abyssinia«, Burgundija »Burgundy«).

- Administrative unit: in North America, the number of such exonyms is twenty-six (12.8\%; e.g., Južna Karolina »South Carolina«, Nova Škotska »Nova Scotia») compared to 221 (6.1\%) in the rest of the world (e.g., Bavarska »Bavaria«, Južna Osetija »South Ossetia«).

- Historical administrative unit: in North America there are no such exonyms (0.0\%) compared to 101 (2.8\%) in the rest of the world (e.g., Galicija "Galicia" in the former Austria-Hungarian Empire, Otomansko cesarstvo »Ottoman Empire«).

- Others: the names of river dams and sluices, parts of settlements, defensive walls (e.g., Kitajski zid »Great Wall«), archaeological sites, tectonic plates, isolated points on the Earth's surface (e.g., Južni tečaj »South Pole«), abbreviated compound geographical names (e.g., Beneluks »Benelux«), and so on; in North America there are no such exonyms $(0.0 \%)$ compared to thirty-four $(0.9 \%)$ in the rest of the world. 


\section{Original language of exonyms}

The original language of Slovenian exonyms from North America is mostly English: in 166 cases (81.4\%) alone and in thirty-two cases (15.7\%) in relation to other languages:

- French eleven times (e.g., Zaliv svetega Lovrenca »Gulf of Saint Lawrence«, French Golfe du Saint Laurent);

- Spanish five times (e.g., Sonorska puščava »Sonoran Desert «, Spanish Desierto de Sonora, belonging to the United States and Mexico);

- Inuit six times (e.g., Otok kralja Viljema »King William Island«, Inuktitut Qikiqtaq in Canada);

- Danish three times (e.g., Baffinov zaliv »Baffin Bay«, Danish Baffin Bugten in the Arctic Ocean);

- Native American languages three times (e.g., Niagarski slapovi »Niagara Falls«, Iroquoian Onguiaahra on the border between the United States and Canada);

- Russian three times (e.g., Beringovo morje »Bering Sea«, Russian Beringovo more in the Pacific Ocean);

- Hawaiian two times (e.g., Havaji »Hawaii«, Hawaiian Hawai»i in Oceania).

French is the original language three times (e.g., Gaspeški polotok» Gaspé Peninsula«, French Peninsula de la Gaspé in Canada), Latin two times (e.g., Nova Škotska »Nova Scotia« in Canada), and Danish once in combination with Inuit (Melvillov zaliv »Melville Bay«, Danish Melville Bugt, Greenlandic Qimusseriarsuaq in the Arctic Ocean).

\section{Degree of Slovenianization of exonyms}

Studying the degree of Slovenianization is demanding and partly subjective. The main problem in developing such typologies is classifying a specific exonym into a single type; due to simplifications, which should ensure sufficiently clear categories, some types overlap and therefore individual names can be classified under several groups.

We determined twelve typological groups of Slovenianization from the smallest to greatest degree of adaptation (Kladnik et al. 2017):

- Exonym from translated common name and original proper name (type A): in North America, the number of such exonyms is seventeen (8.4\%; e.g., jezero Manitoba »Lake Manitoba«, rt Canaveral »Cape Canaveral«) compared to 183 (5.1\%) in the rest of the world (e.g., globel Meteor »Meteor Deep«, plošča Nazca "Nazca Plate«).

- Exonym from translated common name and more or less Slovenianized proper name (type B): in North America, the number of such exonyms is one (0.5\%; e.g., polotok Ungava »Ungava Peninsula ") compared to seventy (1.9\%) in the rest of the world (e.g., gora Fudži »Mount Fuji«, Japanese Fujisan; prekop Majna-Donava »Main-Danube Canal«, German Main-Donau-Kanal).

- Exonym from adopted secondary original name (type C): in North America there are no such exonyms $(0.0 \%)$ compared to 245 (6.8\%) in the rest of the world (e.g., Armenija »Armenia «, Armenian Hayastan; Kanton »Guangzhou«, Chinese Guăngzhōu).

- Exonym from original name with omitted special characters and diacritics (type D): in North America there are no such exonyms (0.0\%) compared to seventy-three (2.0\%) in the rest of the world (e.g., Gdansk »Gdańsk«; Iran »Iran«, Farsi İrān).

- Exonym from transliterated original name with simplified letters and diacritics (type E): in North America there are no such exonyms (0.0\%) compared to 298 (8.2\%) in the rest of the world (e.g., Pandžab »Punjab«; Tokio »Tokyo«, Japanese Tokyō).

- Exonym from transcribed original name with Slovenianized ending (type F): in North America, the number of such exonyms is fifteen (7.4\%; e.g., Aljaska »Alaska «, Kolorado »Colorado«) compared to 191 $(5.3 \%)$ in the rest of the world (e.g., Tirana »Tirana«, Albanian Tiranë; Pariz »Paris«).

- Exonym from borrowed and adapted name (type G): in North America, the number of such exonyms is two (1.0\%; Ellesmere »Ellesmere Island «, Washington »Washington, DC«) compared to $128(3.5 \%)$ in the rest of the world (e.g., Abesinija »Abyssinia«, Italian Abissinia; Nahičevan »Nakhchivan «, Azerbaijani Naxçıvan).

- Exonym with phonetic form of the roots and Slovenianized endings from the Latin suffixes -ia, -ea (type H): in North America, the number of such exonyms is six (2.9\%; e.g., Kalifornija "California", Kolumbija »Columbia River «) compared to 185 (5.1\%) in the rest of the world (e.g., Francija »France«, Azija $»$ Asia $\lll$ ). 
- Exonym with phonetic form of the root and Slovenian ending (type I): in North America, the number of such exonyms is four (2.0\%; e.g., Aleuti »Aleutian Islands«, Apalači »Appalachians « or »Appalachian Mountains «) compared to 220 (6.1\%) in the rest of the world (e.g., Afrika »Africa «, Pireneji »Pyrenees «).

- Exonym from fully translated name (type J): in North America, the number of such exonyms is 159 (77.9\%; e.g., Skalno gorovje »Rocky Mountains «, Veliko suženjsko jezero »Great Slave Lake«) compared to 1,877 (51.9\%) in the rest of the world (e.g., Nizozemska »Netherlands«, Rt dobrega upanja »Cape of Good Hope«).

- Exonym from traditionally Slovenianized name with a trace of the original root (type $K$ ): in North America there are no such exonyms (0.0\%) compared to forty-eight (1.3\%) in the rest of the world (e.g., Rim »Rome«, Italian Roma; Benetke »Venice«, Italian Venezia).

- Exonym from Slovenian name (type L): in North America there are no such exonyms (0.0\%), compared to ninety-seven (2.7\%) in the rest of the world (e.g., Dunaj »Vienna «, German Wien; Nemčija »Germany«, German Deutschland).

\section{Discussion}

The frequency of the current use of Slovenian exonyms was checked in the Gigafida database (Internet 2), which contains 1.2 billion words from publicly available printed texts $(84.4 \%)$ and web texts (15.6\%) published between 1990 and 2011 in Slovenian.

The most commonly used Slovenian exonyms from North America in Slovenian texts are the names of countries and their administrative units.

There are more than five hundred occurrences of Misisipi »Mississippi« (510), Aljaska »Alaska « (572), Kolorado »Colorado« (726), Teksas »Texas« $(1,597)$, Havaji »Hawaii« $(1,819)$, Kolumbija »Columbia« or »Colombia« (1,899), Kalifornija »California« $(2,136)$, Kanada »Canada $(9,174)$, and Združene države Amerike "United States of America» and ZDA

However, the frequency of names for »Mississippi«, »Colorado«, and »Columbia«/»Colombia« is problematic because it conceals the frequencies of the state/district, independent country, and river.

The next most commonly used Slovenian exonyms from North America in Slovenian texts are Dolina smrti »Death Valley« (133), Veliki kanjon »Grand Canyon« (121), Niagarski slapovi »Niagara Falls» (109), Skalno gorovje »Rocky Mountains« (96), and Aleuti »Aleutian Islands« (57).

The exonyms Misisipi »Mississippi«, Aljaska »Alaska«, Kolorado »Colorado«, Teksas »Texas«, and Kanada "Canada « belong to type F (exonym from transcribed original name with Slovenianized ending), the exonyms Kolumbija "Columbia «/»Colombia « and Kalifornija »California" to type H (exonym with phonetic form of the roots and Slovenianized endings from Latin suffixes - $i a$, -ea), the exonyms Havaji »Hawaii « and Aleuti "Aleutian Islands « to type I (exonym with phonetic form of the root and Slovenian ending), and the exonyms Združene države Amerike »United States of America«, Dolina smrti »Death Valley«, Veliki kanjon »Grand Canyon«, Niagarski slapovi »Niagara Falls«, and Skalno gorovje »Rocky Mountains « to type J (exonym from fully translated name).

In its original form, the name Death Valley appears fifty-two times, Grand Canyon 253 times, Niagara Falls twenty-nine times, Rocky Mountains eighty-two times, and Aleutian Islands never.

This means that in modern Slovenian texts, among these five geographical names only the exonym Veliki kanjon "Grand Canyon " occurs less often than the original name Grand Canyon. That means it has not yet been fully established, but the remaining four cases are firmly established Slovenian exonyms.

Among the 3,316 Slovenian exonyms examined from around the world, 204 (6.2\%) occur in North America (i.e., in Canada and the United States). In a comparable Czech list of exonyms (Beránek et al. 2006), out of 2,300 exonyms 1,250 (5.4\%) occur in North America.

Two Polish lists were examined. In the older one (Krauze-Tomczyk and Kondracki 1994a; Krauze-Tomczyk and Kondracki 1994b), out of over six thousand exonyms 245 (3.9\%) were found in Canada and the United States, whereas a somewhat smaller share was found in the most recent Polish publications of geographical names (Internet 3), where, out of 53,000 geographical names and about ten thousand Polish exonyms (Kladnik et al. 2013), 250 (2.5\%) were found in North America. 
Drago Perko, Drago Kladnik, Slovenian exonyms in North America

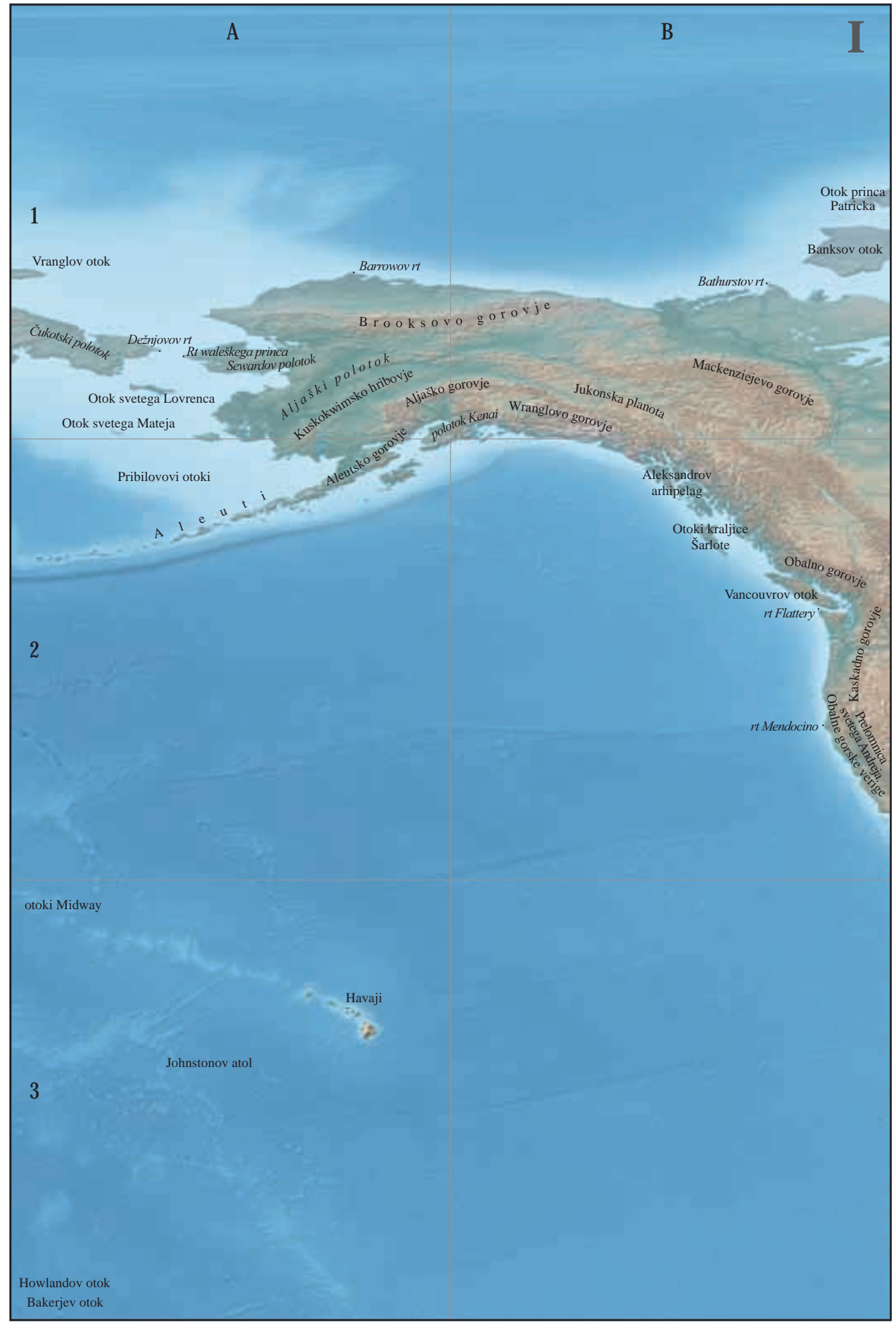


Acta geographica Slovenica, 57-1, 2017

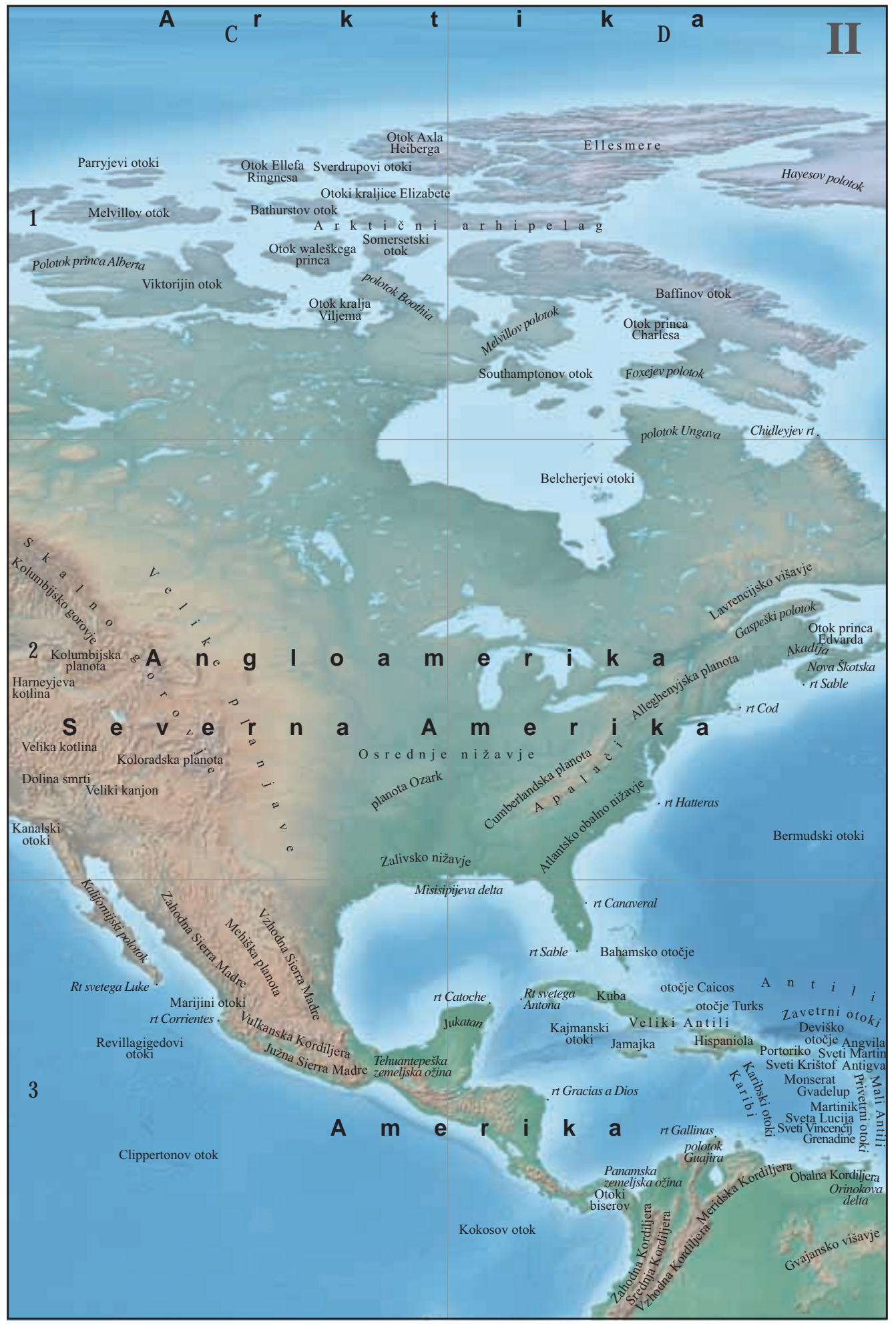


Drago Perko, Drago Kladnik, Slovenian exonyms in North America

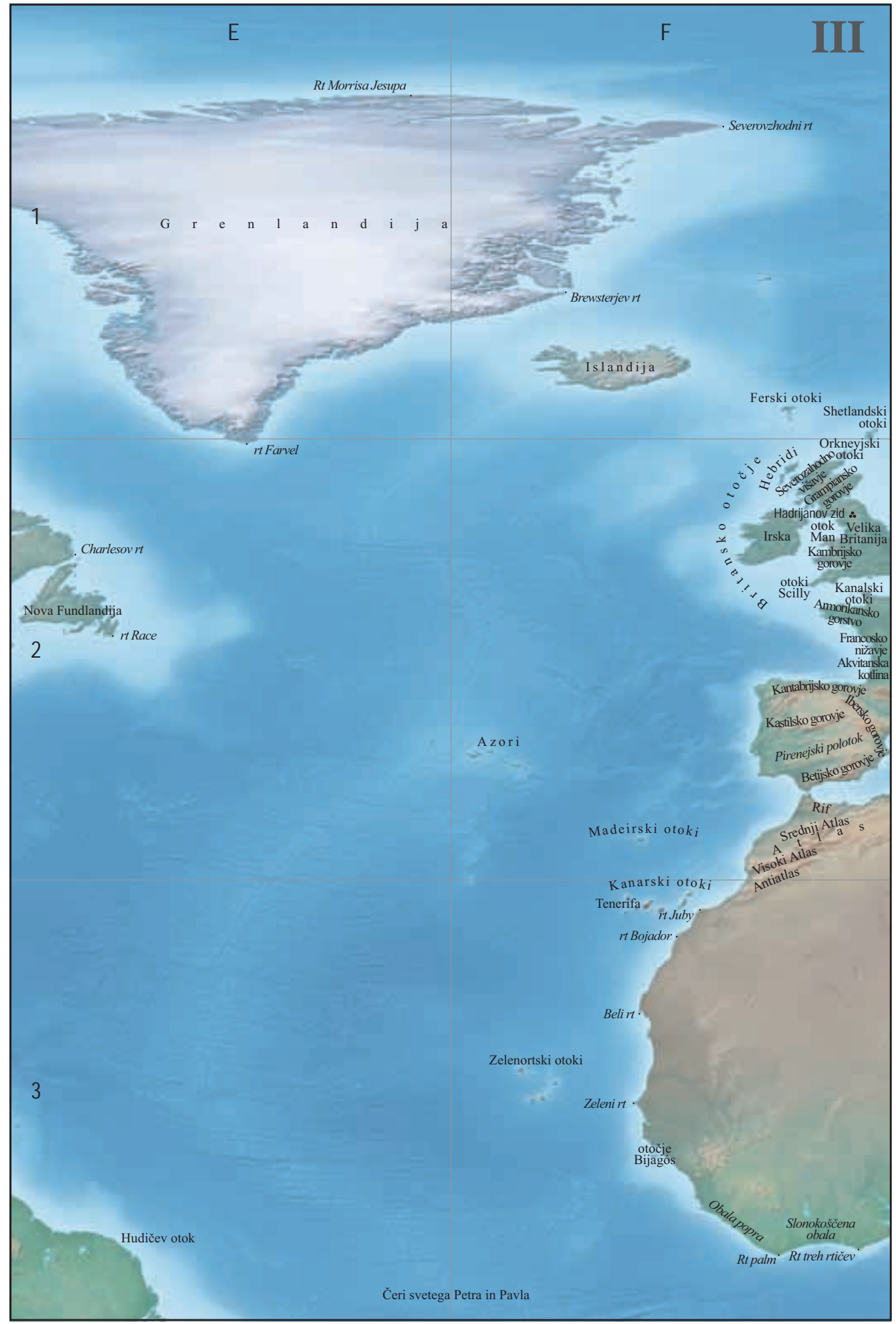




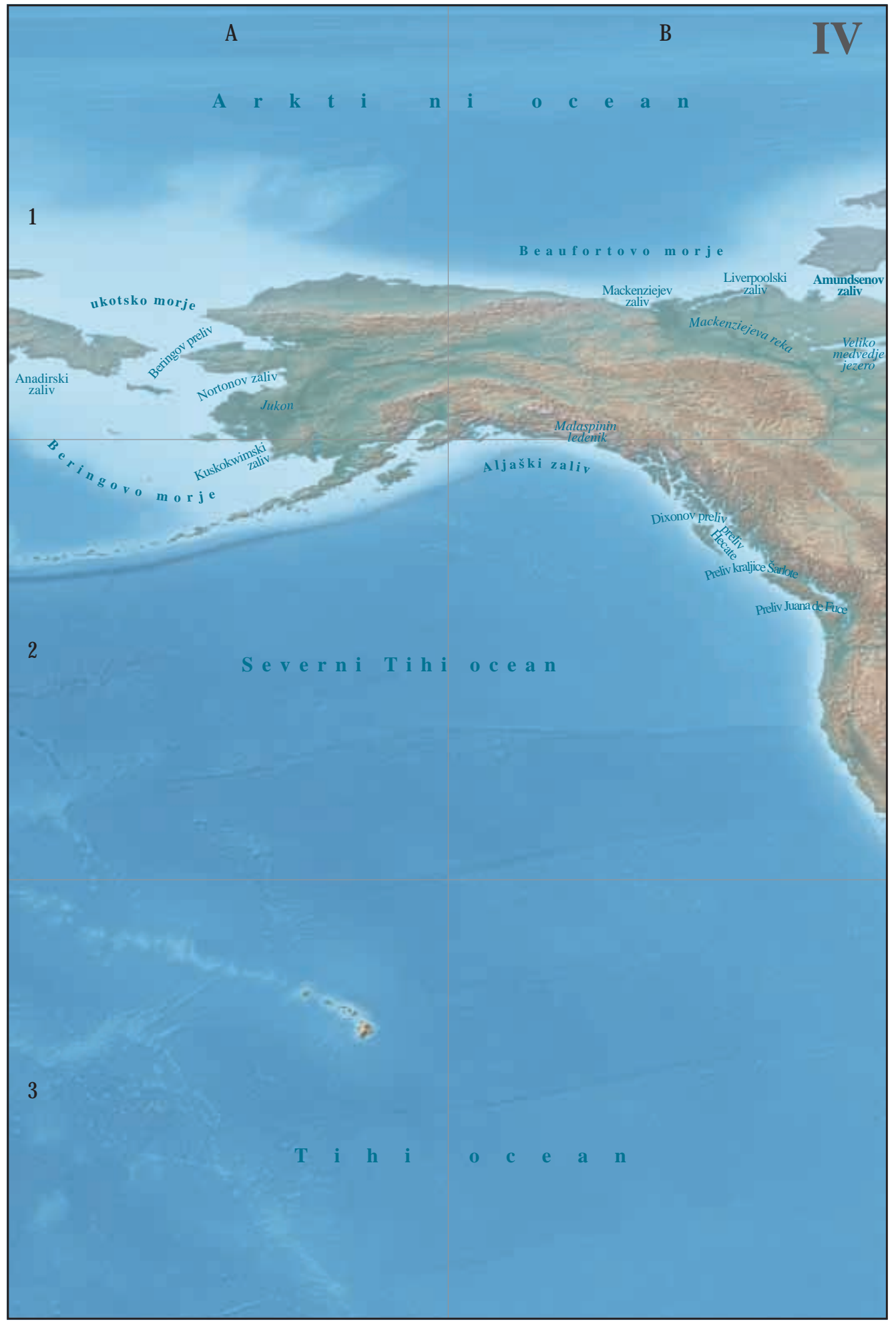


Drago Perko, Drago Kladnik, Slovenian exonyms in North America

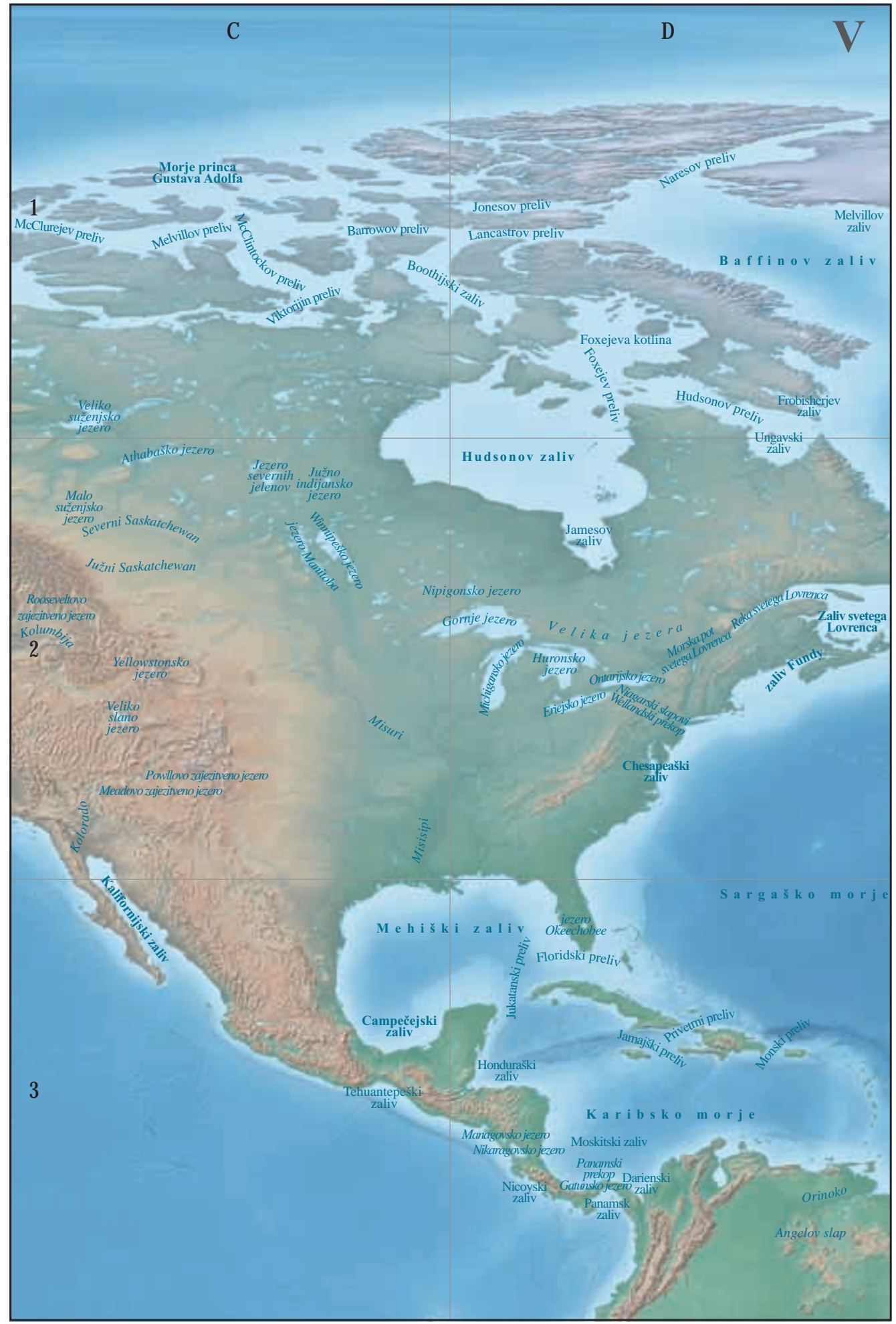




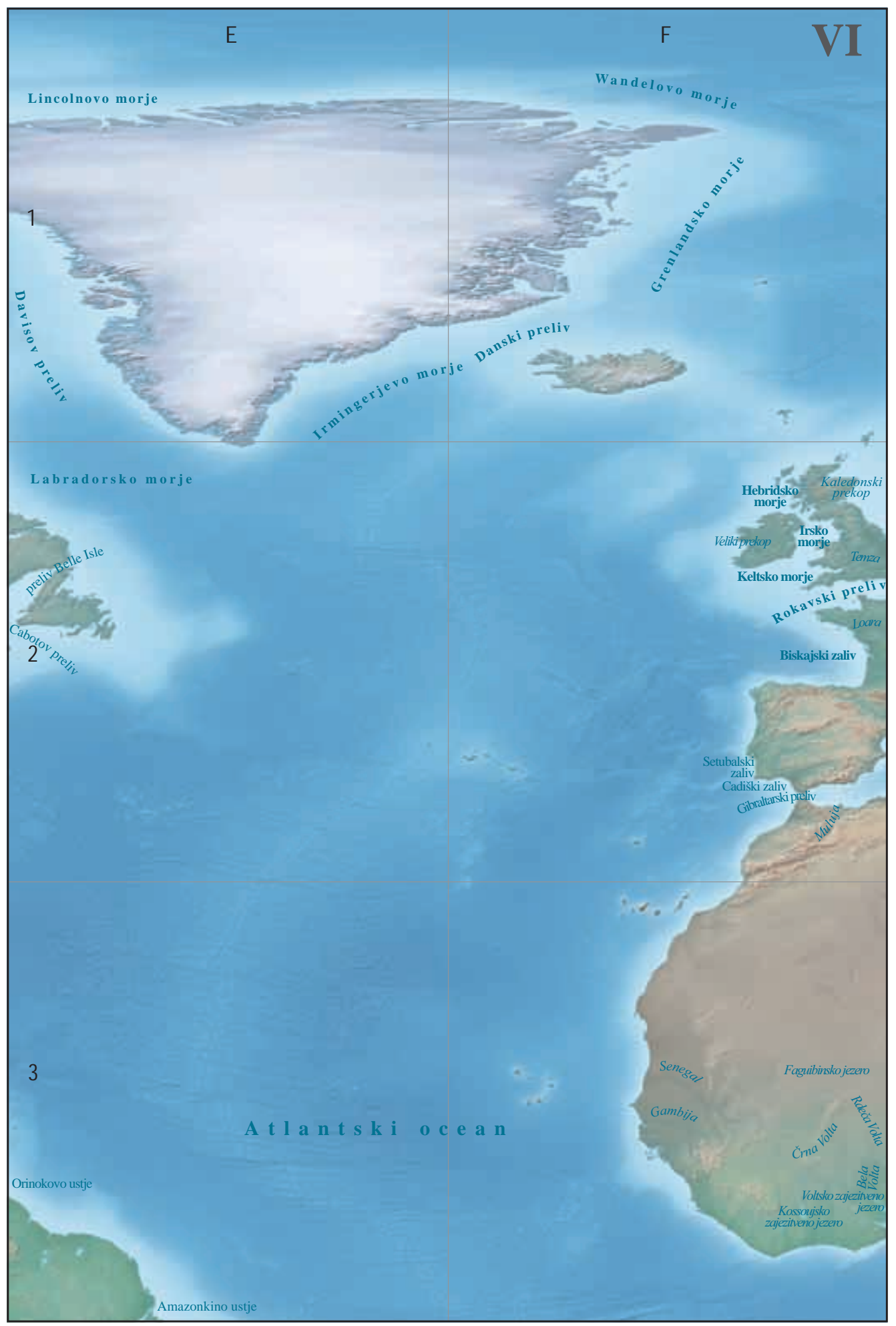


Drago Perko, Drago Kladnik, Slovenian exonyms in North America

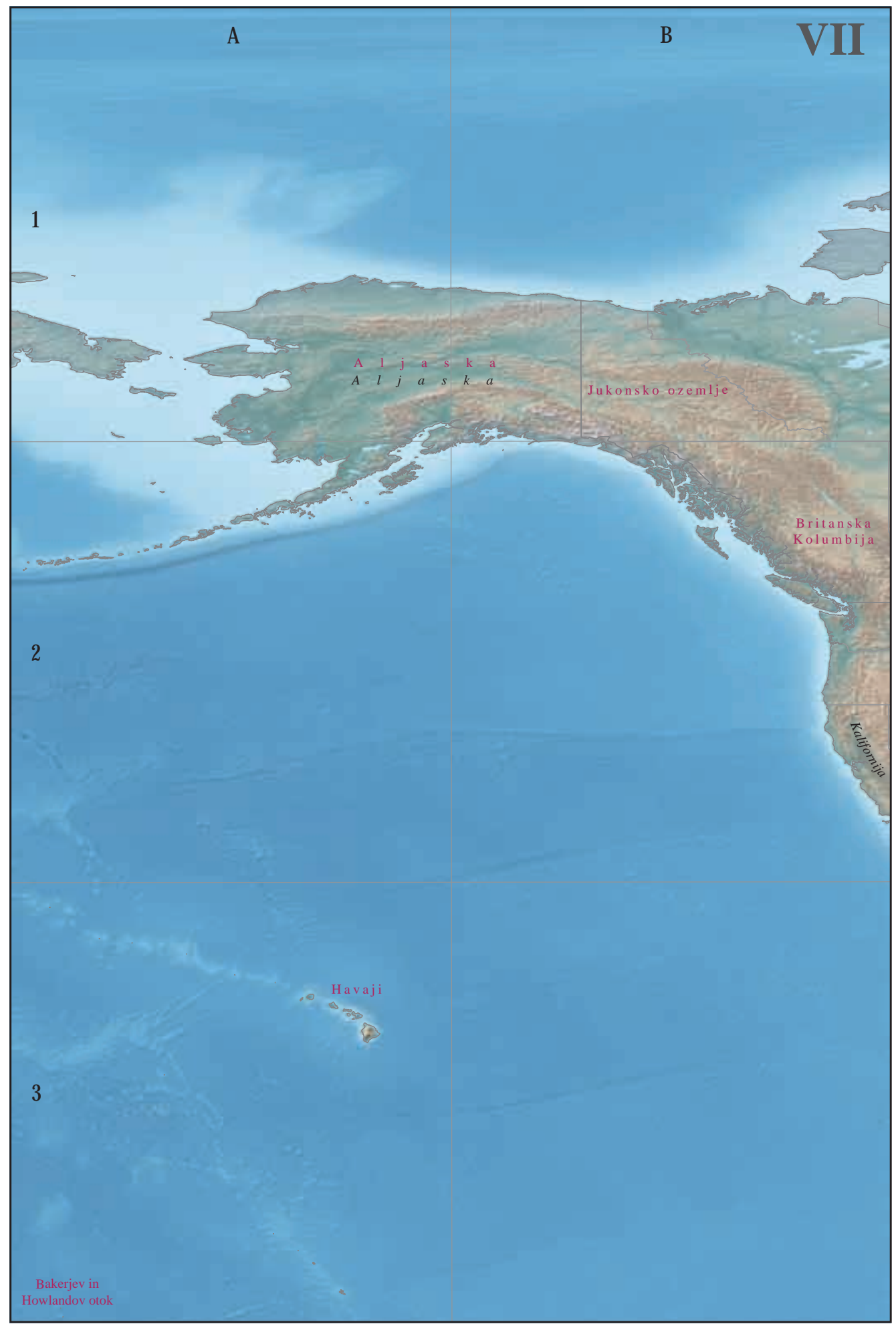




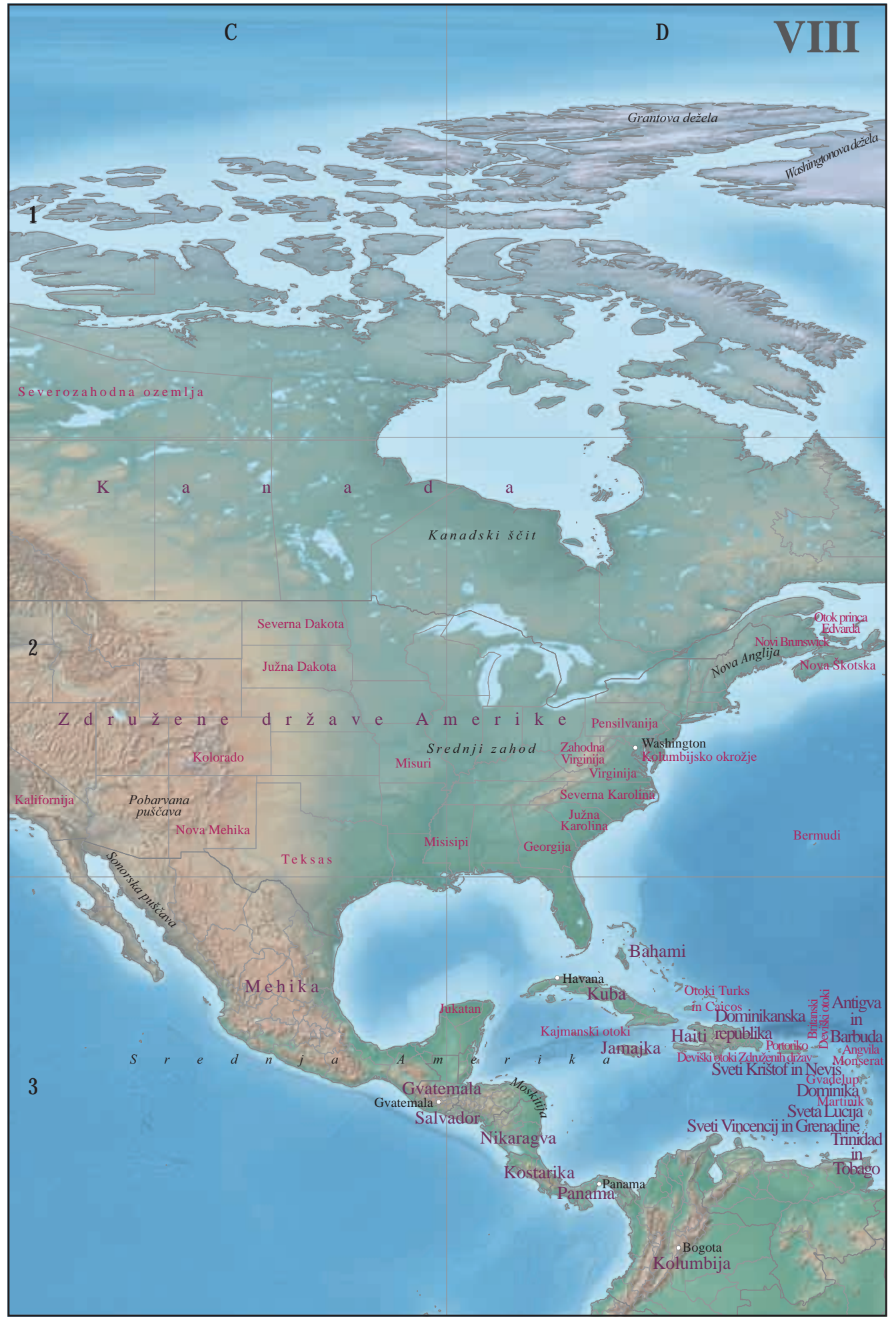


Drago Perko, Drago Kladnik, Slovenian exonyms in North America

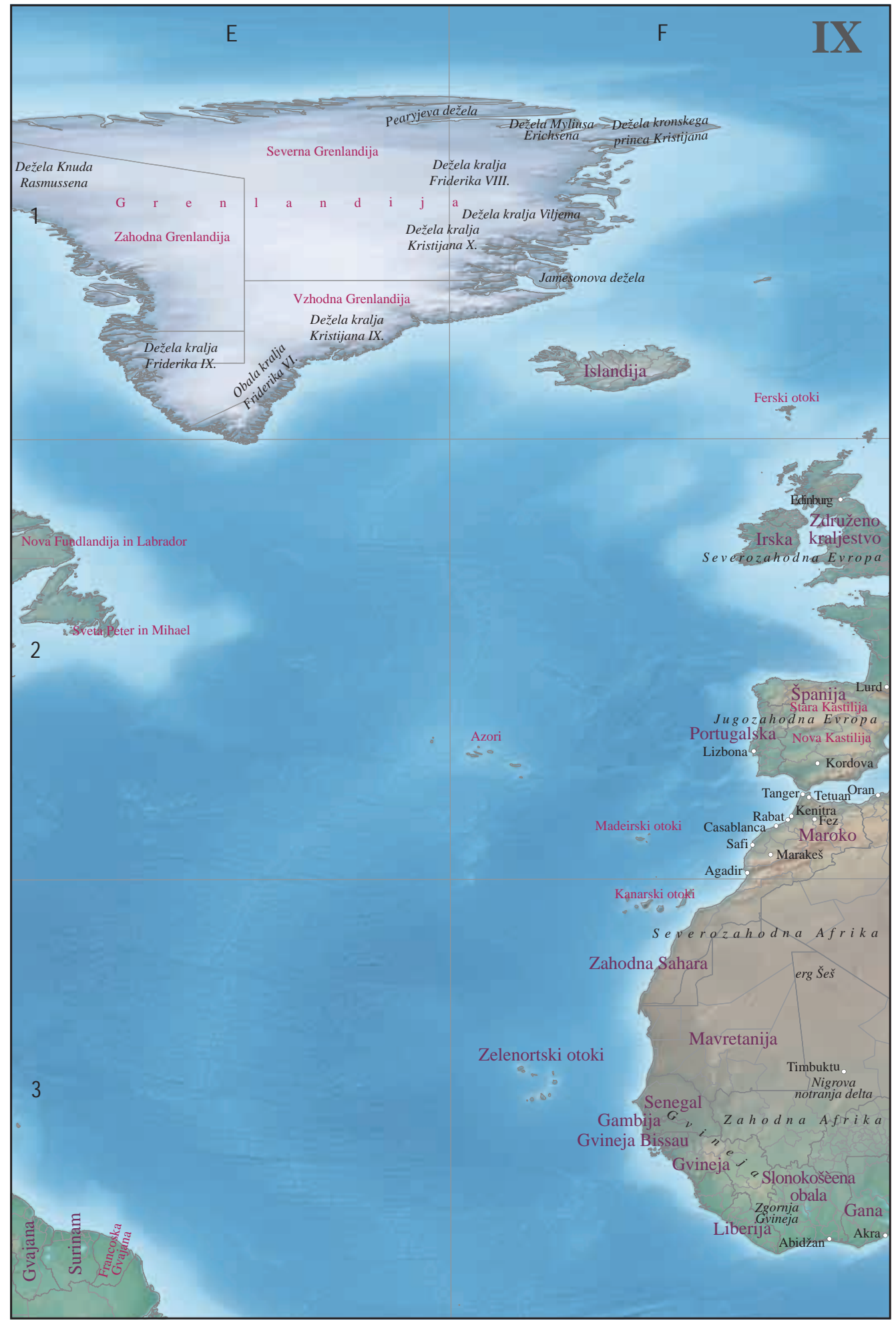


The level of exonymization for all geographical names in the world is therefore lower in Czech than in Slovenian, and for Polish is considerably greater, although the share of Polish exonyms for North America among all Polish exonyms is considerably smaller than the same share of Czech and especially Slovenian exonyms, which once again confirms the greater importance of Slovenian exonyms from North America, which would be expected given the distance of this continent from Slovenia.

ACKNOWLEDGEMENT: The authors acknowledge financial support from the Slovenian Research Agency and the Slovenian Academy of Sciences and Arts (project no. L6-0111: Slovene exonyms: methodology, standardization, GIS, and program no. P6-0101: Geography of Slovenia).

\section{References}

Atlant, 1869-1877. In the bound version of the atlas kept at the National and University Library in Ljubljana. Ljubljana.

Beránek, T., Boháč, P., Drápela, V., Harvalik, M., Liščák, V., Šimůnek, R., Šrámek, R. 2006: Index českých exonym. Prague.

Internet 1: http://giam.zrc-sazu.si/sl/zbirka/zemljepisna-imena\#v (12.10. 2016).

Internet 2: http://eng.slovenscina.eu/korpusi/gigafida (15.10.2016).

Internet 3: http://ksng.gugik.gov.pl/pliki/zeszyty/zeszyt_01.pdf (15.10.2016).

Kadmon, N. 2000: Toponymy: The Lore, Laws and Language of Geographical Names. New York.

Kladnik, D. 2009: Odprte dileme pomenske razmejitve izrazov endonim in eksonim. Geografski vestnik 81-1. Kladnik, D., Ciglič, R., Hrvatin, M., Perko, D., Repolusk, P., Volk, M. 2013: Slovenski eksonimi. Geografija Slovenije 24. Ljubljana.

Kladnik, D., Crljenko, I., Čilaš Šimpraga, A., Geršič, M. 2017: A comparison of Croatian and Slovenian exonyms. Acta geographica Slovenica 57-1. DOI: http://dx.doi.org/10.3986/AGS.4653

Kladnik, D., Urbanc, M., Fridl, J., Orožen Adamič, M., Perko, D. 2006: Ein Kartenfund in Slowenien und sein Faksimilendruck: Ein wichtiges Ereignis für Sloweniens und Österreichs historische Geographie. Mitteilungen der Österreichischen Geographischen Gesellschaft 148.

Krauze-Tomczyk, I., Kondracki, J. 1994a: Polskie nazwy geograficzne świata. Część III Afryka, Ameryka Północna, Ameryka Południowa, Australia i Oceania, Antarktyka. Warszawa.

Krauze-Tomczyk, I., Kondracki, J. 1994b: Polskie nazwy geograficzne świata. Część IV Oceany i morza. Warszawa. Slovenski pravopis, 2001. Ljubljana.

Urbanc, M., Fridl, J., Kladnik, D., Perko, D. 2006: Atlant and slovene national consciousness in the second half of the $19^{\text {th }}$ century. Acta geographica Slovenica 46-2. DOI: http://dx.doi.org/10.3986/AGS46204 Veliki splošni leksikon v osmih knjigah, 1997-1998. Ljubljana. 